\title{
Photosynthetic activity and productivity before and after heading in oats
}

\author{
H. BIRECKA, U. WOJCIESKA
}

In previous investigation spring wheat ( $\mathrm{B}$ ir e $\mathrm{cka}, \mathrm{D}$ a k i c-W $ł$ o dkow ska 1966) and barley (Birecka, Skupińska, Bernstein 1967) grown under the same conditions showed significant differences in the contribution of individual green organs to the total photosynthetic activity at various development stages and in the reaction to a higher dose of nitrogen applied at shooting as regards ageing process of the main shoot, rate of photosynthesis, but especially the final accumulation of assimilates formed after heading. Differences were also found in the contribution of carbon fixed before ear emergence ito the organic matter accumulated in kernels at ripeness.

In the reported two-year experiments carried out at Puławy (Institute of Soil Science and Plant Cultivation) under greenhouse conditions, changes in the role of inidividual green organs in photosynthesis with ageing, as well as the distribution of assimilates in the period from their formation to ripeness were followed in oat plants.

In experiment I (1963) three varieties were investigated: 'Udycz Żółty', 'Blenda' and a crossbred obtained by crossing Avena bisantina with Avena sativa var. 'Heines' and denoted below as 'Avena B/H.' In experiment II (1964) only var. 'Udycz Żółty' was used.

\section{METHODS}

Experiment I - Full sprouting of plants was observed on April 18, beginning of tillering and shooting was noted in all varieties after 14 and 35 days, respectively. The plants were thinned gradually to 11 per pot; the total amount of nutrients added to the $8 \mathrm{~kg}$ soil-sand mixture was: $\mathrm{N}-0.7, \mathrm{P}_{2} \mathrm{O}_{5}-0.6$ and $\mathrm{K}_{2} \mathrm{O}-0.8 \mathrm{~g}$. On the $39^{\text {th }}$ day of growth the plants of each variety were divided into two groups: the first was given 0.2 , the second $-0.7 \mathrm{~g} \mathrm{~N}$ per pot. Heading in all varieties was observed between the $53^{\text {rd }}$ and $57^{\text {th }}$ day (with a delay of one day at high $\mathrm{N}$ level). Full ripeness was noted in all plants on the $91^{\text {s1 }}$ day after sprouting.

Experiment II. Sprouting occurred on April 18-19, beginning of tillering and shooting after 11 and 31 days, respectively. The plants 
were thinned to 8 per pot; the total amount of nutrients added was: $\mathrm{N}-0.8, \mathrm{P}_{2} \mathrm{O}_{5}-0.8$ and $\mathrm{K}_{2} \mathrm{O}-1.2 \mathrm{~g}$. On the $35^{\text {th }}$ day of growth they were divided into two groups and treated similarly as in expt. I. In all plants heading of the main shoot was noted between the $54^{\text {th }}$ and $56^{\text {th }}$ day of growth and that of the tiller two days later. Ripening was observed on the $90^{\text {th }}$ day after sprouting.

It should be added that in both experiments the period, within which the leaves turned yellow, was rather short and fell still to the milk stage of kernels (soon after the $70^{\text {th }}$ day of growth).

\section{Table 1}

Conditions, under which plants were kept in the plexiglass box

\begin{tabular}{|c|c|c|c|c|c|c|}
\hline \multirow{2}{*}{ Exposure } & \multirow{2}{*}{$\begin{array}{l}\text { Age of plants } \\
\text { days }\end{array}$} & \multirow{2}{*}{$\begin{array}{c}\text { Initial } \\
\mathrm{CO}_{2} \text { concen- } \\
\text { tration } \\
\text { vol } \%\end{array}$} & \multicolumn{2}{|c|}{$\begin{array}{l}\text { Fluctuation of temperature } \\
\left({ }^{\circ} \mathrm{C}\right) \text { and weather conditions }\end{array}$} & \multicolumn{2}{|c|}{$\begin{array}{c}{ }^{14} \mathrm{CO}_{2} \text { assimilated-per } \\
\text { cent of total activity } \\
\text { applied }\end{array}$} \\
\hline & & & 'Udycz Żólty' & $\begin{array}{c}\text { 'Avena } \mathbf{B} / \mathrm{H}^{\prime} \text { and } \\
\text { 'Blenda' }\end{array}$ & $\begin{array}{l}\text { 'Udycz } \\
\text { Zólty' }\end{array}$ & $\begin{array}{l}\text { 'Avena } \mathbf{B} / \mathrm{H}^{\prime} \\
\text { and 'Blenda' }\end{array}$ \\
\hline
\end{tabular}

Experiment 19631) - I

\begin{tabular}{r|r|r|r|r|r|r} 
I & 50 & 0.08 & $29-32 ;$ sunny & $27-30 ;$ sunny & 82 & 73 \\
II & 60 & 0.08 & $\begin{array}{r}20-21 ; \text { var. } \\
\text { cloud. }\end{array}$ & $\begin{array}{r}23-26 ; \text { var. } \\
\text { cloud. }\end{array}$ & 61 & 72 \\
III & 70 & 0.068 & $27-30 ; \quad \%$ & $30-34 ;$ sunny & 75 & 77 \\
IV & 79 & 0.033 & $26-30 ;$ sunny & $26-31 ;$ sunny & 22 & 24 \\
\hline
\end{tabular}

Experiment 19641) - II

\begin{tabular}{r|l|l|l|l|l|}
\hline I & 47 & 0.10 & $25-27$; sunny & 78 \\
II & 53 & 0.10 & $31-32 ; \quad "$ & 84 \\
III & 60 & 0.10 & $18-20 ;$ cloudy & 41 \\
IV & 67 & 0.06 & $24-26 ;$ var. \\
cloud. & 78 \\
V & 77 & 0.04 & $28-30 ;$ sunny & 71 & \\
\hline
\end{tabular}

1) Beginning of exposures to ${ }^{14} \mathrm{C}-$ labelled $\mathrm{CO}_{2}$ in 1963: at $1^{15}$ p. m. - 'Udycz Źółty' and at about $2^{15}$ p. m. 'Avena $\mathrm{B} / \mathrm{H}$ ' and 'Blenda'; in 1964 - at $10 \mathrm{a} . \mathrm{m}$.

In both experiments the plants were sampled several times at various intervals, beginming from the $44^{\text {th }}-45^{\text {th }}$ day after sprouting, for dry matter determination, and in the middle of each period between samplings they were exposed in a plexiglass box out-of-doors to ${ }^{14} \mathrm{C}-\mathrm{la}$ belled $\mathrm{CO}_{2}$ for about $20-30$ min.*, (plants var. 'Blenda' and 'Avena $\mathrm{B} / \mathrm{H}$ ' grown on high $\mathrm{N}$ level excepted). In table 1 the conditions, under which the plants were kept in the box, are listed. The labelled plants were

* In addition, in expt. I some plants var. 'Udycz Źbłty' with the flag leaf of the main shoot shaded or with tillers shaded (at high $\mathrm{N}$ level) were introduced into the box; the covers were removed immediately after exposure. 
sampled at various intervals after exposure similarly as in experiments with barley. On the day of exposure samples of green organs for chlorophyll content determination were collected.

All technical procedures applied were the same as in previous investigation on spring wheat. The number of replicates was: for dry matter determination -4 pots, for chlorophyll and radioactivity determination $-2 \times 2$ and $3 \times 2$ plants, respectively.

\section{RESULTS}

In spite of the fact that in experiment II with 'Udycz Żólty' in the control the nitrogen supply per plant was better than in experiment I, in both years the total final weight as well as the grain yield of the main

Table 2

Weight of oats 'Udycz Żółty'1) - g d. m. per plant

\begin{tabular}{l|c|c|c|c|c}
\hline \multirow{2}{*}{$\begin{array}{c}\text { Age of } \\
\text { plants } \\
\text { days }\end{array}$} & \multicolumn{2}{|c|}{ Low nitrogen dose } & \multicolumn{2}{c}{ High nitrogen dose } \\
\cline { 2 - 3 } & main shoot & fertile tillers & main shoot \\
total $\mid$ grain only $\left.{ }^{2}\right)$ & total $\mid$ grain only $\left.{ }^{2}\right)$ & total $\mid$ grain only $\left.{ }^{2}\right)$ & total $\mid$ grain only $\left.{ }^{2}\right)$ \\
\hline
\end{tabular}

Experiment I

\begin{tabular}{l|l|l|l|l|l|l|l|l}
\hline 45 & 2.41 & 0.04 & - & - & 2.35 & 0.06 & 0.12 & \\
55 & 4.16 & 0.47 & - & - & 4.33 & 0.55 & 0.33 & \\
65 & 5.55 & 1.18 & - & - & 5.90 & 1.36 & 0.70 & \\
75 & 6.66 & 2.59 & - & - & 7.40 & 3.36 & 0.68 & 0.13 \\
83 & 7.22 & 3.25 & - & - & 8.28 & 4.08 & 0.88 & 0.22 \\
91 & 7.19 & 3.42 & - & - & 8.06 & $4.00^{*}$ & 0.75 & 0.22 \\
\hline
\end{tabular}

Experiment II

\begin{tabular}{l|l|l|l|l|l|l|l|l}
\hline 44 & 2.01 & 0.03 & 0.30 & & 1.87 & 0.02 & 0.64 & \\
51 & 3.60 & 0.27 & 0.70 & 0.04 & 3.58 & 0.20 & 1.24 & 0.02 \\
57 & 4.52 & 0.59 & 1.02 & 0.08 & 4.79 & 0.67 & 1.58 & 0.15 \\
63 & 5.78 & 1.31 & 1.51 & 0.27 & 6.24 & 1.33 & 2.65 & 0.51 \\
72 & 6.80 & 2.75 & 2.22 & 0.81 & 7.86 & 3.32 & 3.30 & 1.30 \\
81 & 6.98 & 3.10 & 2.05 & 0.90 & 8.20 & 3.92 & 2.98 & 1.26 \\
90 & 7.12 & 3.32 & $1.973)$ & 0.88 & 8.44 & $\left.4.10^{*}\right)$ & $\left.2.71^{3}\right)$ & 1.24 \\
\hline
\end{tabular}

1) In expt. I (low $\mathrm{N}$ dose) the weight of sterile tillers was $0.09-0.13 \mathrm{~g}$, they died after heading. In expt. II on both $\mathrm{N}$ levels their weight varied between 0.29 and $0.39 \mathrm{~g}$; the number of fertile tillers in both treatments was about 0.9 .

$\left.{ }^{2}\right)$ Number of kernels in the main shoot in expt. I: low $\mathrm{N}-119$, high $\mathrm{N}$ dose -137 , in expt. II-121 and 143, respectively; in tillers (expt. II) 45 and 60.

${ }^{3}$ ) Weight of the culm: low $\mathrm{N}-0.46$, high $\mathrm{N}$ dose $-0.67 \mathrm{~g}$.

* Differences depending on $\mathrm{N}$ dose statistically significant $(\mathrm{p}=0,05)$.

shoot were similar (Table 2). Some differences in the weight of individual parts could be observed, i.e. in expt. II the weight of the culm (without sheaths) was somewhat lower and that of the laminae, sheaths and panicle somewhat higher than in expt. I (Fig. 1); differences in chlorophyll (Tabs. 3 and 4) as well as nitrogen content (Table 5) were not great. The 


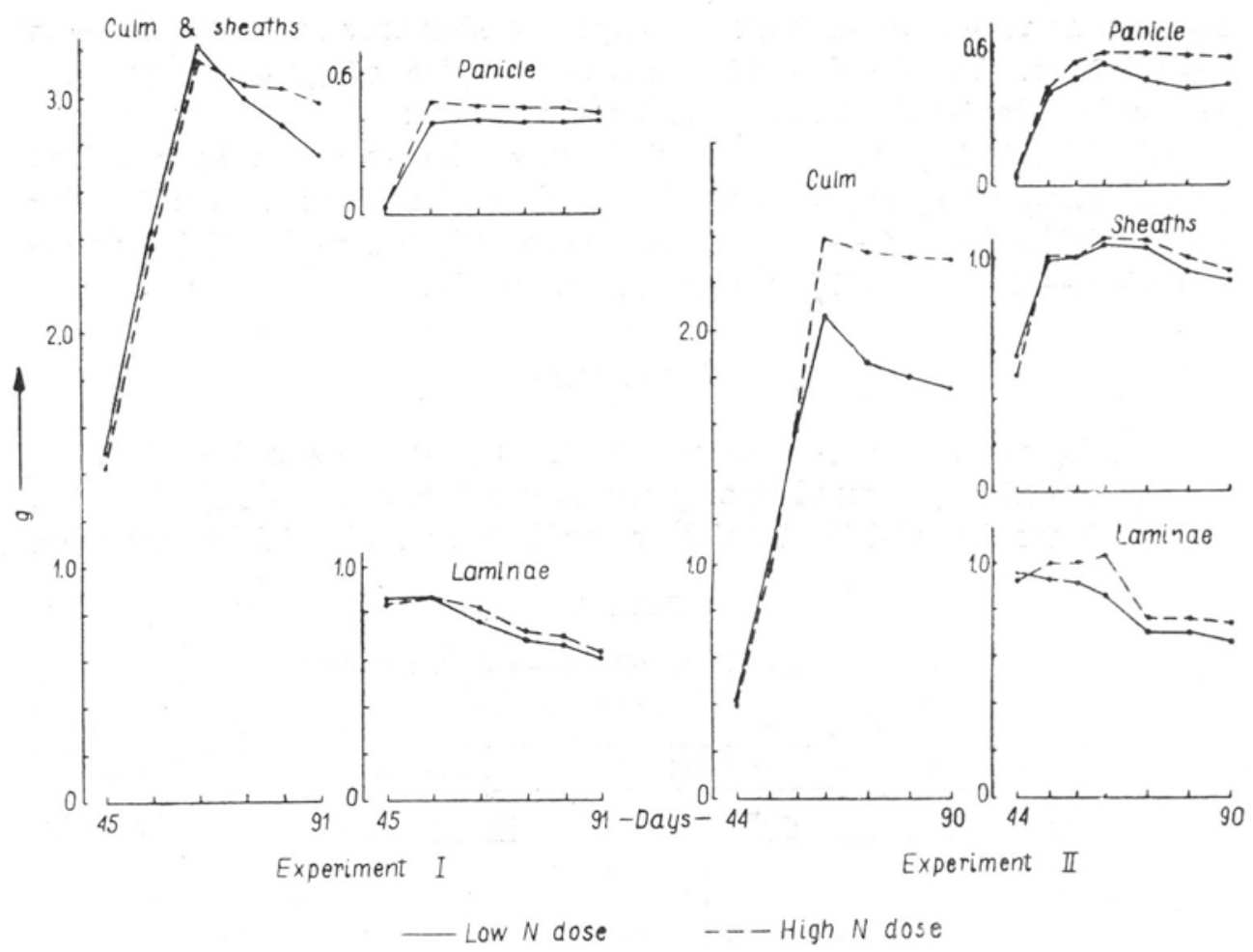

Fig. 1. Dry weight ${ }^{1}$ ) of particular plant parts of ,Udycz Żółty' 1) In expt. I weight of sheaths varied between 0.91 (55th day) and $0.82 \mathrm{~g}$ (at ripeness).

better nitrogen supply* in control plants influenced mainly the growth of tillers.

The higher nitrogen dose applied at shooting brought about very rapidly an increase in $\mathrm{N}$ content in the plants. In both experiments the greatest differences in this respect between treatments occurred already about 10 days after $\mathrm{N}$ application. Very marked differences in chlorophyll content in leaves were also manifested. In the later period the plants at higher $\mathrm{N}$ level - as compared to the controls - contained almost twice as much more chlorophyll. In the main shoot the total lamina area was not greatly affected (Table 6). However, after heading the green area of laminae was under larger $\mathrm{N}$ supply significantly larger; in both experiments the weight of leaves was somewhat higher than in the control. Greater differences were observed in the weight of the panicle as well as in the weight of the culm at later development stages; in control plants the decrease in dry matter of the culm after 63-65 days of growth till ripeness was significant, whereas at high $\mathrm{N}$ level changes in its weight in this period were very small.

* And perhaps some other favourable growth factors. 
At ripeness the greater weight of the main shoot due to better $\mathrm{N}$ supply was revealed in both experiments not only in the higher culm weight but also in the greater, of about 20 per cent, yield (and number) of kernels. However, the relative strongest reaction to $N$ applied at shooting was manifested by the fertile tiller; this is seen in the weight

Table 3

Chlorophyll content in oats - mg per plant

Experiment I

\begin{tabular}{|c|c|c|c|c|c|c|c|c|c|c|c|c|c|c|c|c|}
\hline \multirow{4}{*}{ Plant parts ${ }^{1}$ ) } & \multicolumn{8}{|c|}{ 'Udycz Żółty' } & \multicolumn{4}{|c|}{ 'Avena $\mathbf{B} / \mathrm{H}^{\prime}$} & \multicolumn{4}{|c|}{ 'Blenda' } \\
\hline & \multicolumn{4}{|c|}{ low $\mathrm{N}$ dose } & \multicolumn{4}{|c|}{ high $\mathrm{N}$ dose } & \multicolumn{8}{|c|}{ low $\mathrm{N}$ dose } \\
\hline & \multicolumn{16}{|c|}{ age of plants - days } \\
\hline & 50 & 60 & 70 & 79 & 50 & 60 & 70 & 79 & 50 & 60 & 70 & 79 & 50 & 60 & 70 & 79 \\
\hline \multicolumn{17}{|l|}{ M. shoot } \\
\hline \multicolumn{17}{|l|}{ laminae } \\
\hline $1^{\text {st }}$ & 0.8 & 0.8 & 0.8 & & 1.2 & 1.3 & 1.0 & & 1.0 & 1.1 & 0.7 & & 0.9 & 1.0 & 0.5 & \\
\hline $2^{\text {nd }}$ & 1.6 & 1.7 & 1.2 & & 2.3 & 2.3 & 1.9 & & 1.8 & 1.2 & 0.9 & & 2.0 & 1.7 & 1.1 & \\
\hline $3^{\text {rd }}$ & 1.8 & 1.3 & 0.5 & & 2.4 & 2.2 & 1.3 & & 1.8 & 1.0 & 0.4 & & 2.0 & 1.5 & 0.8 & \\
\hline $4^{\text {th }}$ & 1.8 & 1.2 & tr. & & 2.3 & 1.7 & 0.5 & & 1.6 & 0.6 & 0.1 & & 2.1 & 1.1 & 0.3 & \\
\hline $5^{\text {th }}$ & 1.5 & 0.7 & - & & 2.0 & 1.3 & - & & 0.9 & 0.3 & - & & 1.7 & 0.7 & - & \\
\hline rem. & 1.3 & - & - & & 1.7 & 0.4 & - & & 0.5 & - & - & & 1.4 & 0.2 & - & \\
\hline total & 8.8 & 5.7 & 2.5 & - & $\mid 11.9$ & 9.2 & 4.7 & 0.2 & 7.6 & 4.2 & 2.1 & - & 10.1 & 6.2 & 2.7 & - \\
\hline \multicolumn{17}{|l|}{ sheaths } \\
\hline $1^{\text {st }}$ & 0.7 & 1.2 & 1.0 & 0.2 & 1.3 & 2.0 & 1.8 & 0.4 & 0.8 & 1.0 & 0.8 & 0.2 & 0.8 & 1.0 & 0.5 & 0.2 \\
\hline $2^{\text {nd }}$ & 0.4 & 0.5 & 0.3 & tr. & 0.8 & 0.8 & 0.6 & 0.1 & 0.3 & 0.2 & 0.2 & 0.1 & 0.4 & 0.4 & 0.4 & tr. \\
\hline $3^{\mathrm{rd}}$ & 0.2 & 0.3 & 0.1 & - & 0.4 & 0.4 & 0.3 & tr. & 0.2 & 0.1 & 0.1 & - & 0.2 & 0.1 & 0.2 & - \\
\hline $4^{\text {th }}$ & 0.1 & 0.1 & 0.1 & - & 0.2 & 0.2 & 0.2 & - & 0.2 & 0.1 & 0.1 & - & 0.2 & 0.2 & 0.1 & - \\
\hline rem. & 0.3 & 0.1 & tr. & - & 0.4 & 0.2 & tr. & - & 0.2 & 0.1 & tr. & - & 0.4 & 0.2 & 0.1 & - \\
\hline total & 1.7 & 2.2 & 1.5 & 0.2 & 3.1 & 3.6 & 2.9 & 0.5 & 1.7 & 1.5 & 1.2 & 0.3 & 2.0 & 1.9 & 1.3 & 0.2 \\
\hline \multicolumn{17}{|l|}{ internodes } \\
\hline $1^{\text {st }}$ & tr. & 0.1 & 0.3 & 0.1 & tr. & 0.3 & 0.5 & 0.2 & tr. & 0.2 & 0.3 & 0.1 & tr. & 0.2 & 0.4 & 0.1 \\
\hline $2^{\text {nd }}$ & 0.1 & 0.3 & 0.1 & tr. & 0.2 & 0.4 & 0.2 & 0.1 & 0.1 & 0.1 & 0.1 & tr. & 0.1 & 0.1 & 0.1 & tr. \\
\hline $3^{\text {rd }}$ & 0.1 & 0.2 & 0.1 & - & 0.1 & 0.3 & 0.1 & - & 0.1 & 0.1 & 0.1 & - & 0.1 & 0.1 & 0.1 & - \\
\hline rem. & 0.1 & 0.3 & tr. & - & 0.2 & 0.3 & 0.1 & - & 0.1 & 0.2 & tr. & - & 0.1 & 0.2 & 0.1 & - \\
\hline total & 0.3 & 0.9 & 0.5 & 0.1 & 0.5 & 1.3 & 0.9 & 0.3 & 0.3 & 0.6 & 0.5 & 0.1 & 0.3 & 0.6 & 0.7 & 0.1 \\
\hline rachis & & 0.3 & 0.3 & 0.1 & & 0.5 & 0.4 & 0.1 & & 0.2 & 0.3 & 0.2 & & 0.3 & 0.2 & 0.1 \\
\hline glumes & 0.3 & 1.2 & 1.0 & 0.3 & 0.5 & 1.6 & 1.9 & 0.7 & 0.6 & 0.9 & 0.7 & 0.6 & 0.5 & 1.0 & 1.1 & 0.5 \\
\hline kernels & & 0.8 & 0.8 & 0.4 & & 1.0 & 1.0 & 0.3 & & 0.6 & 0.7 & 0.4 & & 0.6 & 0.7 & 0.3 \\
\hline total & 11.1 & 11.1 & 6.6 & 1.1 & 16.0 & 17.2 & 11.8 & 2.1 & 10.2 & 8.0 & 5.5 & 1.6 & 12.9 & 10.6 & 6.7 & 1.2 \\
\hline tillers & 0.9 & $|0.3|$ & - & -1 & 0.8 & 3.3 & $\mid 1.3$ & 1.3 & 0.9 & 0.1 & - & $1-1$ & $|0.7|$ & 0.1 & - & - \\
\hline
\end{tabular}

1) M. shoot - main shoot; 1st - uppermost. 


\section{Table 4}

Chlorophyll content in oats 'Udycz Żóty' $-\mathrm{mg}$ per plant Experiment II

\begin{tabular}{|c|c|c|c|c|c|c|c|c|}
\hline \multirow{4}{*}{ Plant parts } & \multicolumn{4}{|c|}{ Low nitrogen dose } & \multicolumn{4}{|c|}{ High nitrogen dose } \\
\hline & \multicolumn{8}{|c|}{ age of plants - days } \\
\hline & \multicolumn{2}{|c|}{$\left.47^{1}\right)$} & \multicolumn{2}{|c|}{60} & \multicolumn{2}{|c|}{$\left.47^{1}\right)$} & \multicolumn{2}{|c|}{60} \\
\hline & $\mathbf{M}$ & $\mathbf{T}$ & $\mathbf{M}$ & $\mathbf{T}$ & $\mathbf{M}$ & $\mathbf{T}$ & $\mathbf{M}$ & $\mathbf{T}$ \\
\hline \multicolumn{9}{|l|}{ laminae } \\
\hline $1^{\text {st }}$ & $1.1(2.6)$ & $0.3(2.3)$ & 0.8 & 0.3 & $1.2(2.5)$ & $0.4(2.2)$ & 1.6 & 0.7 \\
\hline $2^{\text {nd }}$ & $2.3(2.8)$ & $0.9(2.6)$ & 1.7 & 0.8 & $3.1(2.6)$ & $1.5(2.6)$ & 2.9 & 1.7 \\
\hline $3^{\text {rd }}$ & $2.6(2.5)$ & $1.2(2.5)$ & 1.7 & 1.0 & $3.4(2.4)$ & $1.6(2.5)$ & 2.3 & 1.6 \\
\hline $4^{\text {th }}$ & $2.4(2.2)$ & $1.2(2.4)$ & 1.3 & 0.7 & $2.9(2.3)$ & $1.4(2.4)$ & 2.0 & 1.1 \\
\hline $5^{\text {th }}$ & $1.5(2.2)$ & $1.2(2.4)$ & 0.8 & 0.2 & $2.2(2.3)$ & $1.3(2.3)$ & 1.6 & 0.6 \\
\hline $6^{\text {th }}$ & $0.7(2.1)$ & $0.5(2.1)$ & 0.1 & - & $1.6(2.2)$ & $0.6(2.2)$ & 0.2 & 0.3 \\
\hline $7^{\text {th }}$ & $0.1(1.6)$ & 0.1 & - & & $0.8(2.2)$ & $0.3(2.2)$ & - & \\
\hline total & 10.7 & 5.4 & 6.4 & 3.0 & 15.2 & 7.1 & 10.6 & 6.0 \\
\hline sheaths & $1.3(2.1)$ & $0.4(2.2)$ & 1.7 & 0.7 & $2.2(2.2)$ & $0.6(2.3)$ & 2.9 & 1.9 \\
\hline culm & $0.3(1.6)$ & $0.2(1.5)$ & 0.5 & 0.3 & $0.4(1.7)$ & $0.2(1.6)$ & 0.8 & 0.4 \\
\hline panicle & $0.1(1.4)$ & & 1.3 & 0.6 & $0.2(1.4)$ & & 1.8 & 1.1 \\
\hline kernels & & & 0.6 & 0.1 & & & 0.7 & 0.1 \\
\hline total & 12.4 & 6.0 & 10.5 & 4.7 & 18.0 & 7.9 & 16.8 & 9.5 \\
\hline
\end{tabular}

1) $\mathrm{M}$ - main shoot, $\mathrm{T}$ - tillers; in parantheses-chlor. $\mathrm{a}$ : chlor. b ratio

\section{Table 5}

Total nitrogen content in oats 'Udycz Żółty' - mg per plant

\begin{tabular}{|c|c|c|c|c|c|c|c|c|}
\hline \multirow{3}{*}{$\begin{array}{c}\text { Age } \\
\text { of plants } \\
\text { days }\end{array}$} & \multicolumn{4}{|c|}{ Low nitrogen dose } & \multicolumn{4}{|c|}{ High nitrogen dose } \\
\hline & \multicolumn{2}{|c|}{ main shoot } & \multicolumn{2}{|c|}{ tillers } & \multicolumn{2}{|c|}{ main shoot } & \multicolumn{2}{|c|}{ tillers } \\
\hline & total & grain only & total & grain only & total & grain only & total & grain only \\
\hline \multicolumn{9}{|c|}{ Experiment I } \\
\hline 45 & 36.6 & & 2.4 & & 58.2 & & 3.4 & \\
\hline 911) & 50.9 & 44.5 & & & 72.0 & 64.0 & 5.6 & 3.2 \\
\hline \multicolumn{9}{|c|}{ Experiment II } \\
\hline 44 & 34.9 & & 6.0 & & 63.0 & & 16.3 & \\
\hline 90 & 59.8 & 50.8 & 16.0 & 13.6 & 83.9 & 71.0 & 24.6 & 20.8 \\
\hline
\end{tabular}

1) $\mathrm{N}$ content in 'Avena $\mathrm{B} / \mathrm{H}$ ': low $\mathrm{N}-40$, high $\mathrm{N}$ dose -59 in the main shoot and $15 \mathrm{mg}$ in tillers; in 'Blenda' 37 and $55 \mathrm{mg}$ (plus $14 \mathrm{mg}$ in tillers), respectively. 
Table 6

Green lamina area of the main shoot $\left(\mathrm{cm}^{2}\right)$

Experiment I

\begin{tabular}{|c|c|c|c|c|c|c|c|c|c|c|c|c|}
\hline \multirow{4}{*}{$\begin{array}{l}\text { Lami- } \\
\left.\text { nae }^{1}\right)\end{array}$} & \multicolumn{6}{|c|}{ 'Udycz Żółty' } & \multicolumn{3}{|c|}{ 'Avena B/H' } & \multicolumn{3}{|c|}{ 'Blenda' } \\
\hline & \multicolumn{3}{|c|}{ low $\mathrm{N}$ dose } & \multicolumn{3}{|c|}{ high $\mathrm{N}$ dose $\mathrm{e}^{2}$ ) } & \multicolumn{6}{|c|}{ low $\mathrm{N}$ dose } \\
\hline & \multicolumn{12}{|c|}{ age of plants - days } \\
\hline & 50 & 60 & 70 & 50 & 60 & 70 & 50 & 60 & 70 & 50 & 60 & 70 \\
\hline $1^{\text {st }}$ & 23.3 & 22.2 & 21.4 & 26.4 & 26.0 & 23.0 & 30.9 & 30.0 & 28.7 & 18.8 & 19.6 & 15.4 \\
\hline $2^{\text {nd }}$ & 46.8 & 42.6 & 42.8 & 52.0 & 47.6 & 45.7 & 52.0 & 43.9 & 44.0 & 43.0 & 42.6 & 40.4 \\
\hline $3^{\text {rd }}$ & 52.8 & 45.8 & 29,7 & 54.0 & 50.2 & 50.6 & 49.3 & 43.5 & 33.3 & 46.1 & 44.3 & 44.2 \\
\hline $4^{\text {th }}$ & 56.5 & 47.6 & - & 55.1 & 47.1 & 30.0 & 46.7 & 43.0 & 7.0 & 51.5 & 41.1 & 33.8 \\
\hline $5^{\text {th }}$ & 54.4 & 37.6 & - & 54.7 & 39.6 & - & 36.3 & 26.8 & - & 50.1 & 28.7 & - \\
\hline $6^{\text {th }}$ & 41.4 & tr. & - & 40.0 & 13.2 & - & 22.0 & - & - & 31.5 & 12.5 & - \\
\hline $7^{\text {th }}$ & 20.5 & - & - & 20.1 & - & - & - & - & 一 & 23.0 & - & - \\
\hline ota & 295.7 & 195.8 & 93.9 & 302.3 & 223.7 & 149.3 & 237.2 & 187.2 & 113.0 & 264.0 & 188.8 & 133.8 \\
\hline
\end{tabular}

1) First lamina = the uppermost one.

$\left.{ }^{2}\right)$ On the 78 th day the total green lamina area accounted for about $16 \mathrm{~cm}^{2}$.

as well as in mitrogen and chlorophyll content of its particular green parts.

The two other oat varieties investigated in expt.I showed some differences as compared to 'Udycz Żółty'. The differences were revealed partly in the surface area of the uppermost leaf as well as of the lowest ones. The total green lamina area significantly lower before heading than in 'Udycz Zółty', at the end of milk stage of kernels was in both varieties higher than in the former; this was due mainly to the delayed senescence of lower leaves. The differences in green lamina area between varieties were reflected also in chlorophyll content in the investigated plants.

The weight increments of the main shoot in 'Blenda' till the $75^{\text {th }}$ day of growth were higher than in 'Avena $\mathrm{B} / \mathrm{H}$ ' (Table 7). However, its final total-weight, culm weight, as well as the grain yield in both of them were similar, but lower than in 'Udycz Żólty' (by about 10-15 per cent); the number of kernels was also lower than in the latter. In contrast to 'Udycz Żółty' the better $\mathrm{N}$ supply at shooting did not cause any marked weight increase of the main shoot either in 'Blenda' or in 'Avena B/H'. The differences observed between treatments in the number of kernels and in their weight are not statistically significant. On the other hand the tillers of 'Avena $\mathrm{B} / \mathrm{H}$ ' and 'Blenda' reacted to nitrogen much stronger than those of 'Udycz Źółty'. It is worth noting that in all varieties a better $\mathrm{N}$ supply enhancing the growth of tillers suppressed transiently soon after its application the growth of the main shoot culm. 


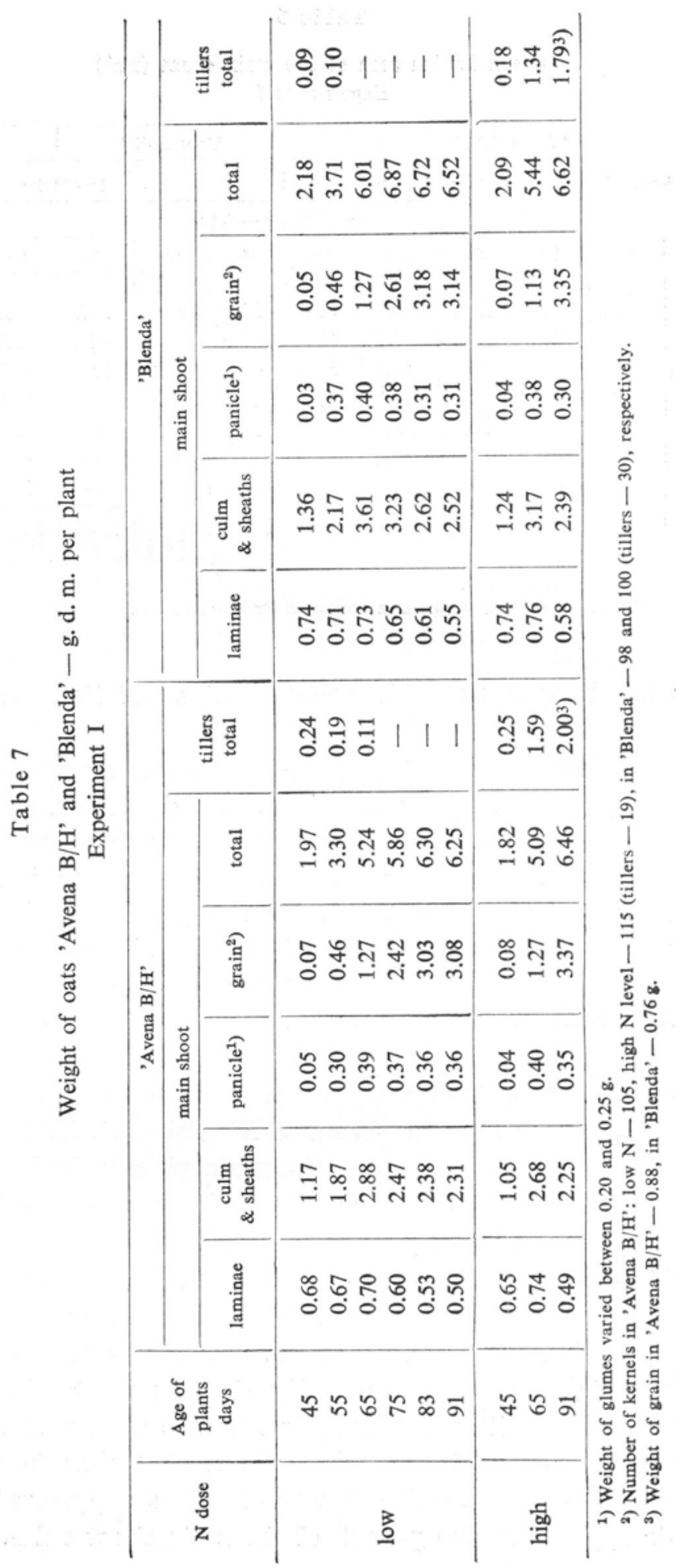




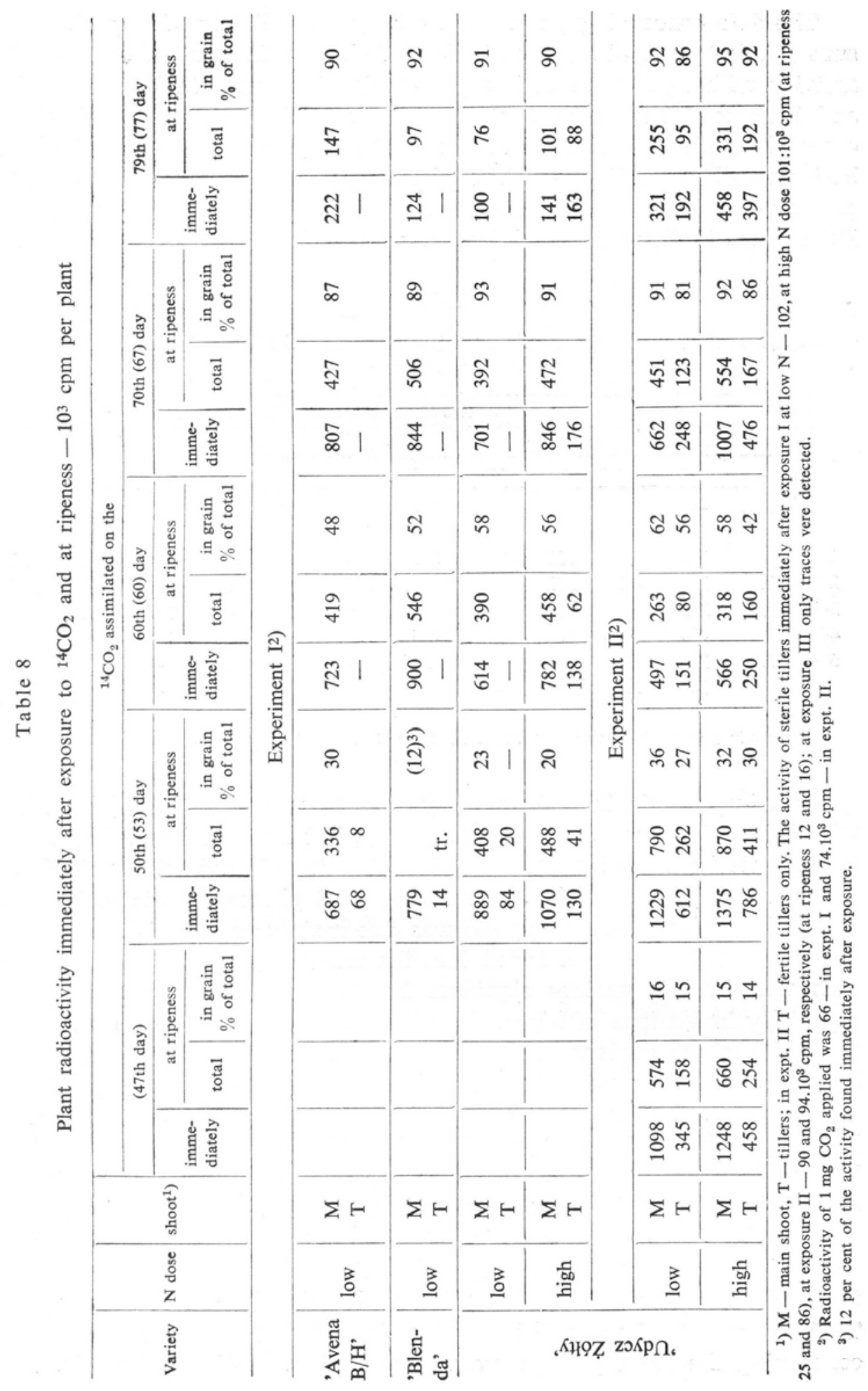


The data concerning plant radioactivity immediately after each exposure (Table 8) cannot serve as indices of changes in plant photosynthetic activity with ageing. In both experiments differences in light in'tensity and temperature influenced this process to such an extent that in some cases older plants exposed even to lower $\mathrm{CO}_{2}$ concentration but under better weather conditions exhibited higher photosynthetic activity than plants $7-10$ days earlier under worse light and temperature conditions. Differences in these external factors seem to have influenced in expt. I

Table 9

Chlorophyll content $(\mathrm{mg})$ and ${ }^{14} \mathrm{C}$ assimilated $\left(10^{3} \mathrm{cpm}\right)$ per $\mathrm{dm}^{2}$ of green lamina in 'Avena $\mathrm{B} / \mathrm{H}^{\text {' }}$ Experiment I

\begin{tabular}{|c|c|c|c|c|c|c|c|c|c|c|c|c|}
\hline \multirow{4}{*}{ Laminae } & \multicolumn{12}{|c|}{ Age of plants - days } \\
\hline & \multicolumn{4}{|c|}{50} & \multicolumn{4}{|c|}{60} & \multicolumn{4}{|c|}{70} \\
\hline & \multicolumn{2}{|c|}{ 'Avena $\mathbf{B} / \mathrm{H}^{\prime}$} & \multicolumn{2}{|c|}{ 'Blenda' } & \multicolumn{2}{|c|}{ 'Avena B/H' } & \multicolumn{2}{|c|}{ 'Blenda' } & \multicolumn{2}{|c|}{ 'Avena B/H' } & \multicolumn{2}{|c|}{ 'Blenda' } \\
\hline & chlor. & ${ }^{14} \mathrm{C}$ & chlor. & ${ }^{14} \mathrm{C}$ & chlor. & ${ }^{14} \mathrm{C}$ & chlor. & ${ }^{14} \mathrm{C}$ & chlor. & ${ }^{14} \mathrm{C}$ & chlor. & ${ }^{14} \mathrm{C}$ \\
\hline $1^{\text {st }}$ & 4.5 & 233 & 5.0 & 335 & 3.6 & 267 & 5.0 & 342 & 2.4 & 302 & 3.0 & 332 \\
\hline $2^{\text {nd }}$ & 3.6 & 231 & 4.7 & 302 & 2.7 & 255 & 3.7 & 333 & 2.0 & 300 & 2.7 & 340 \\
\hline $3^{\text {rd }}$ & 3.5 & 215 & 4.4 & 258 & 2.2 & 216 & 3.6 & 248 & 1.1 & 216 & $2.41)$ & \\
\hline $4^{\text {th }}$ & 3.5 & 174 & 4.1 & 167 & 1.4 & 116 & 2.7 & 144 & 0.9 & 140 & 1.9 & \\
\hline $5^{\text {th }}$ & 2.7 & 160 & 3.4 & 144 & 1.0 & 33 & $\left.2.3^{1}\right)$ & & - & - & & \\
\hline $6^{\text {th }}$ & 2.2 & 144 & $\left.3.1^{11}\right)$ & & - & & 1.3 & & - & - & & \\
\hline
\end{tabular}

1) Radioactivity of this lamina was determined together with that of the lowest one.

also photosynthesis in 'Udycz Żólty' and 'Avena B/H' placed together with 'Blenda' in the box on the same day, but an hour later. These two latter varieties at each stage under investigation did not behave similarly as regards $\mathrm{CO}_{2}$ assimilation. The higher total photosynthetic activity of 'Blenda' (the last stage excepted) was due mainly to the higher activity of its leaves; it should be added that the rate of photosynthesis per area unit was in this variety significantly greater than in 'Avena B/H', especially in laminae of higher insertion order (Table 9). It is true that the chlorophyll conitent per area unit was also greater in 'Blenda', however, the differences in $\mathrm{CO}_{2}$ fixation do not seem to be closely related to the observed differences in chlorophyll content. The contribution of laminae to the total photosynthetic activity before heading accounited in both varieties for more than 70 per cent, in the later stages it diminished, but more rapidly in 'Avena $\mathrm{B} / \mathrm{H}$ ' than in 'Blenda' (Fig. 2). In both of them the contribution of sheaths varied between 18 and 22 (with the dominating role of the uppermost one) and that of the culm (the uppermost internode also dominating) changed after heading from 7 to 12 per cent. Taking account of some ${ }^{14} \mathrm{C}$ translocation during exposure the values concerning the culm perhaps even somewhat overestimate its role. The 
'Avena $\mathrm{B} / \mathrm{H}$ '

'Blenda'

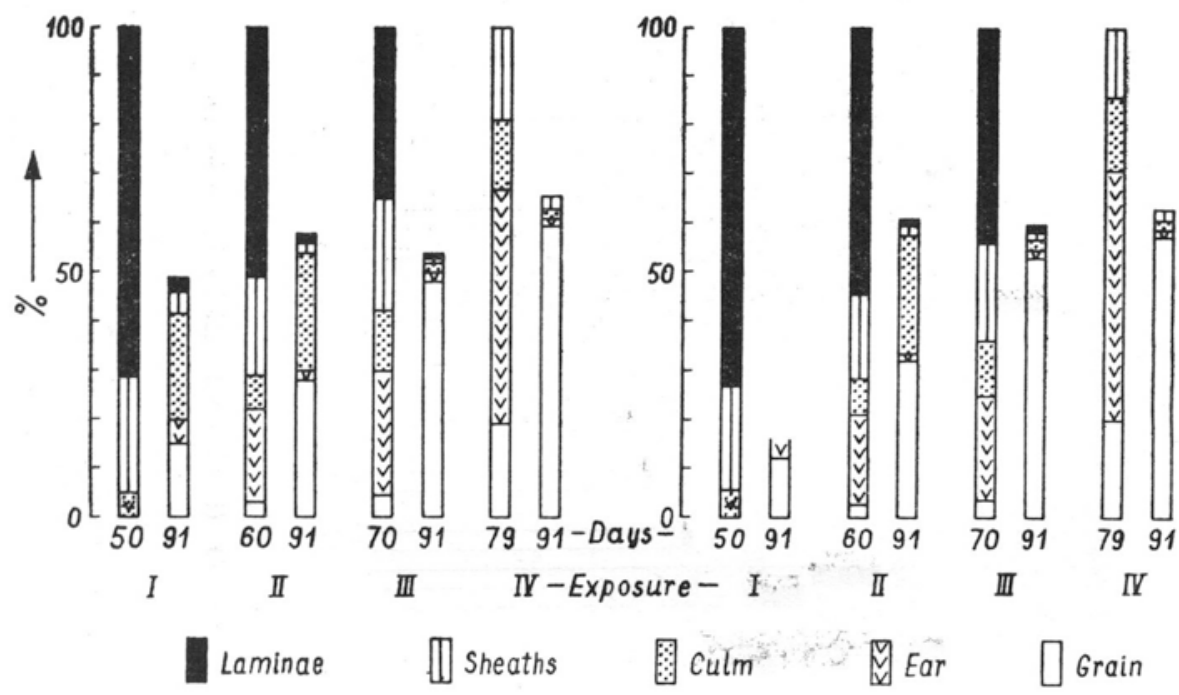

ig. 2. Radioactivity of the main shoot of 'Avena $\mathrm{B} / \mathrm{H}$ ' and 'Blenda' immediately after exposure and at ripeness (total shoot activity immediately after exposure $-100 \%$ )

Experiment I

contribution of the panicle including kernels ranged from 22 to 30 per cent for a long time, being somewhat lower in 'Blenda'; afterwards it increased rapidly amounting on the $79^{\text {th }}$ day in both varieties to about 70 per cent. The control plants var. 'Udycz Źólty' give a similar picture as regards changes with time in the contribution of particular green parts to the total shoot photosynthetic activity (Fig. 3). The data obtained (Table 10) clearly show that before heading as well as soon after anthesis ( $60^{\text {th }}$ day) the photosynthetic activity of the flag leaf lamina was smaller than that of the two lower ones, but the activity of its sheath was the highest. The contribution of the uppermost leaf including the corresponding internoide was increasing during the whole period unider investigation, but did not exceed markedly 30 per cent of the total photosynthetic activity (in 'Blenda' it did not exceed even 20 per cenit).

The contribution of lower laminae did not correspond to their contribution to the total green area. The lower was their insertion order the lower was the photosynthesis rate per area unit (Table 11); only the second lamina did not show differences in comparison with the uppermost one (the later development stages excepted)*. It is worth noting that

* In 'Avena B/H' and 'Blenda' no differences between the two uppermost laminae were found even on the $70^{\text {th }}$ day of growth. 


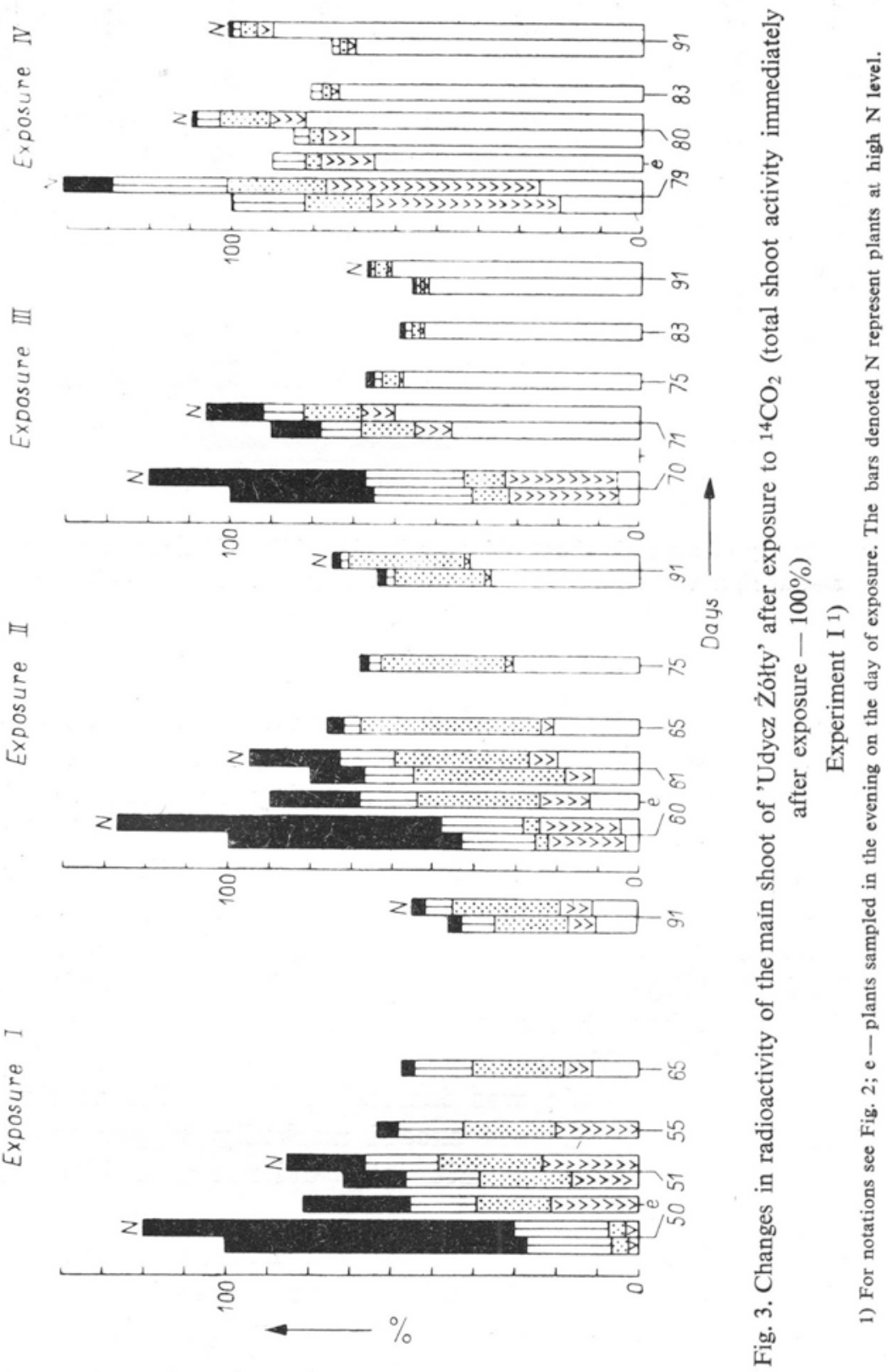


Table 10

Contribution of particular green parts to the total photosynthetic activity of the main shoot (\%) Experiment I

\begin{tabular}{|c|c|c|c|c|c|c|c|c|c|c|c|c|c|c|}
\hline \multirow{5}{*}{$\begin{array}{c}\text { Plant } \\
\text { parts }\end{array}$} & \multicolumn{8}{|c|}{ 'Udycz Źółty' } & \multicolumn{3}{|c|}{ 'Avena $\mathrm{B} / \mathrm{H}^{\prime}$} & \multicolumn{3}{|c|}{ 'Blenda' } \\
\hline & \multicolumn{14}{|c|}{ age of plants - days } \\
\hline & \multicolumn{2}{|c|}{50} & \multicolumn{2}{|c|}{60} & \multicolumn{2}{|c|}{70} & \multicolumn{2}{|c|}{79} & \multirow[t]{2}{*}{50} & \multirow[t]{2}{*}{60} & \multirow[t]{2}{*}{70} & \multirow[t]{2}{*}{\begin{tabular}{|l}
$\mid 50$ \\
\end{tabular}} & \multirow[t]{2}{*}{ | 60} & \multirow[t]{2}{*}{70} \\
\hline & \multicolumn{8}{|c|}{ nitrogen dose } & & & & & & \\
\hline & low & high & low & high & low & high & low & high & \multicolumn{6}{|c|}{ low } \\
\hline total & 100 & 100 & 100 & 100 & 100 & 100 & $10 J$ & 100 & 100 & 100 & 100 & 100 & 100 & 100 \\
\hline panicle $^{1}$ ) & & & 22 & 18 & 32 & 27 & 66 & 55 & & 22 & 30 & & 21 & 25 \\
\hline $1^{\text {st }}$ leaf & & & & & & & & & & & & & & \\
\hline lamina & 10 & 10 & 9 & 8 & 13 & 12 & - & 7 & 10 & 11 & 12 & 9 & 9 & 7 \\
\hline sheath & 7 & 7 & 9 & 7 & 13 & 12 & 17 & 23 & 8 & 11 & 12 & 8 & 8 & 7 \\
\hline $1^{\text {st }}$ intn..$\left.^{2}\right)$ & 一 & - & 1 & 1 & 6 & 6 & 14 & 11 & tr. & 4 & 6 & tr. & 3 & 6 \\
\hline total & 17 & 17 & 19 & 16 & 32 & 30 & 31 & 41 & 18 & 26 & 30 & 17 & 20 & 20 \\
\hline $2^{\text {nd }}$ leaf & & & & & & & & & & & & & & \\
\hline lamina & 20 & 19 & 17 & 15 & 16 & 16 & - & 1 & 17 & 15 & 15 & 14 & 16 & 16 \\
\hline sheath & 5 & 4 & 4 & 3 & 5 & 4 & 1 & 1 & 5 & 3 & 8 & 5 & 5 & 6 \\
\hline $2^{\text {nd }}$ intn. & 1 & 1 & 1 & 1 & 2 & 2 & 2 & 2 & 2 & 1 & 2 & 1 & 1 & 1 \\
\hline total & 26 & 24 & 22 & 19 & 23 & 22 & 3 & 4 & 24 & 19 & 25 & 20 & 22 & 23 \\
\hline $3^{\text {rd }}$ leaf & & & & & & & & & & & & & & \\
\hline lamina & 14 & 16 & 13 & 14 & 6 & 12 & & & 15 & 13 & 9 & 17 & 14 & \\
\hline sheath & 3 & 4 & 3 & 2 & 5 & 3 & & & 4 & 2 & 2 & 4 & 3 & \\
\hline $3^{\text {rd }}$ intn. & 1 & 1 & tr. & tr. & 1 & 1 & & & 1 & 1 & 1 & 1 & 1 & \\
\hline total & 18 & 21 & 16 & 16 & 12 & 16 & - & - & 20 & 16 & 12 & 22 & 18 & \\
\hline $4^{\text {th }}$ leaf & & & & & & & & & & & & & & \\
\hline lamina & 12 & 15 & 12 & 13 & - & 5 & & & 13 & 7 & 1 & 12 & 8 & \\
\hline sheath & 2 & 2 & 1 & 1 & tr. & 1 & & & 3 & 2 & 2 & 2 & 2 & \\
\hline $4^{\text {th }}$ intn. & 1 & 1 & tr. & tr. & tr. & tr. & & & 1 & 1 & tr. & 1 & 1 & \\
\hline total & 15 & 18 & 13 & 14 & tr. & 6 & - & - & 17 & 10 & 3 & 15 & 11 & \\
\hline
\end{tabular}

1) Including kernels. On the 79 th day the contribution of the panicle was $67 \%$-in 'Avena B/H' and $71 \%$-in 'Blenda'

$\left.{ }^{2}\right)$ Radioactivity of the 1st (uppermost) internode is due mainly to its part non covered by the sheath.

the investigated in expt. I varieties differed from each other significantly as regards changes with time in chlorophyll content per $\mathrm{dm}^{2}$ in particular leaves.

The reaction of plants var. 'Udycz Żółty' to the higher $\mathrm{N}$ dose in photosynthesis was noted already on the $50^{\text {th }}$ day of growth, i.e. 11 days after its application (expt. I). The increase in the total photosynthetic activity - as indicated by the plant radioactivity — varied between 20 and 27 per cent, with the exception of the last development period, when an increase of about 40 per cent was nated. The greater $\mathrm{CO}_{2}$ fixation was 
due mainly to a higher activity of the laminae. The reaction of other green organs, the last period excepted, in spite of an increased chlorophyll content was very week. The higher photosynthetic activity of laminae was due not only to their greater total green area, but also to a higher rate of photosynthesis per area unit. In this respect the reaction of individual laminae was different. The two uppermost laminae, differing in chlorophyll content in dependence on $\mathrm{N}$ supply, at both levels showed analogous rates of photosynthesis, in the case when it amounted to about 17 (exposure I) as well as when it was about $11-12 \mathrm{mg}$ $\mathrm{CO}_{2} \cdot \mathrm{dm}^{-2} \cdot \mathrm{h}^{-1}$ (exposure II).

Table 11

Chlorophyll content $(\mathrm{mg})$ and ${ }^{14} \mathrm{C}$ assimilated $\left(10^{3} \mathrm{cpm}\right)$ per $\mathrm{dm}^{2}$ of green lamina in 'Udycz Żółty' Experiment I

\begin{tabular}{|c|c|c|c|c|c|c|c|c|c|c|c|c|}
\hline \multirow{5}{*}{ Laminae } & \multicolumn{12}{|c|}{ Age of plants - days } \\
\hline & \multicolumn{4}{|c|}{$\left.50^{1}\right)$} & \multicolumn{4}{|c|}{$\left.60^{1}\right)$} & \multicolumn{4}{|c|}{70} \\
\hline & \multicolumn{12}{|c|}{ nitrogen dose } \\
\hline & \multicolumn{2}{|c|}{ low } & \multicolumn{2}{|c|}{ high } & \multicolumn{2}{|c|}{ low } & \multicolumn{2}{|c|}{ high } & \multicolumn{2}{|c|}{ low } & \multicolumn{2}{|c|}{ high } \\
\hline & chlor. & ${ }^{14} \mathrm{C}$ & chlor. & ${ }^{14} \mathrm{C}$ & chlor. & ${ }^{14} \mathrm{C}$ & chlor. & ${ }^{14} \mathrm{C}$ & chlor. & ${ }^{14} \mathrm{C}$ & chlor. & ${ }^{14} \mathrm{C}$ \\
\hline $1^{\text {st }}$ & 3.4 & 386 & 4.4 & 386 & 3.8 & 238 & 5.0 & 251 & 3.8 & 420 & 4.2 & 429 \\
\hline $2^{\text {nd }}$ & 3.3 & 371 & 4.5 & 382 & 3.9 & 236 & 4.8 & 248 & 2.9 & 262 & 4.1 & 297 \\
\hline $3^{\text {rd }}$ & 3.3 & 238 & 4.2 & 322 & 2.9 & 183 & 4.5 & 231 & 1.6 & 138 & 2.6 & 189 \\
\hline $4^{\text {th }}$ & 3.3 & 187 & 4.2 & 282 & 2.7 & 145 & 3.7 & 220 & - & 一 & 1.6 & 134 \\
\hline $5^{\text {th }}$ & 2.7 & 149 & 3.6 & 188 & 1.8 & 79 & 3.2 & 166 & - & 一 & - & 一 \\
\hline $6^{\text {th }}$ & 2.5 & 106 & 3.1 & 110 & tr. & tr. & 2.6 & 140 & - & - & - & 一 \\
\hline $7^{\text {th }}$ & 1.2 & 3 & 2.2 & 5 & 一 & 一 & - & - & - & - & - & - \\
\hline
\end{tabular}

1) $400.10^{3} \mathrm{cpm}$ corresponded to about $18 \mathrm{mg} \mathrm{CO} \cdot \mathrm{dm}^{-2} \cdot \mathrm{h}^{-1}$.

The influence of $\mathrm{N}$ on assimilation rates was clearly manifested in lower laminae (the lowest ones excepted), however in all cases their values were lower than those in the two uppermost ones.

As the higher dose of $\mathrm{N}$ influenced photosynithesis mainly in the laminae, their contribution to the total shoot activity - as compared to the controls - increased and that of other green parts, especially of the panicle decreased.

In control plants of expt. II changes with ageing in the contribution

Fig. 4. Changes in radioactivity of shoots of 'Udycz Żólty' after exposure to ${ }^{14} \mathrm{CO}_{2}$ (total shoot activity immediately after exposure $-100 \%$ )

Experiment II ${ }^{1}$ )

1) For notations see fig. 2; in most cases, the first sampling excepted, laminae were analysed together with sheaths. The bars denoted $\mathrm{N}$ represent plants at high $\mathrm{N}$ level; radioacivity of successive laminae immediately after exposure is indicanted by distances between white points. 
of the investigated green parts of the main shoot (Fig. 4) were similar to those observed in expt. I. It should be, however, noted that the contribution of the laminae was somewhat higher and that of the culm significantly lower.

Similarly as in the first experiment the higher $N$ dose applied at shooting influenced photosynthesis of the main shoot very rapidly. However, the magnitude of the increase in $\mathrm{CO}_{2}$ assimilation till the $60^{\text {th }}$ day of growth was lower, ranging between 12 and 14 per cent independently of the date of exposure as well as of differences in temperature and light intensity during exposure. On the other hand 67-days-old plainits reacted to $\mathrm{N}$ in photosynthesis much stronger than did 70-days-old plants in expt. I $\left(\mathrm{CO}_{2}\right.$ concentration, temperature and light intensity were not very different).

The higher phatosynthetic activity of the main shoot was due mainly to a greater $\mathrm{CO}_{2}$ fixation in the laminae. In the later period an increase in this respect was observed also in the sheaths as well as in the panicle.

A much stronger reaction to $\mathrm{N}$ was shown by the tiller. Before heading the increase in photosynthesis was about 30 per cent and in the later period it reached gradually a value twofold higher than that in the control.

In the control tiller at all stages under investigation the contribution of the laminae was greater (changing from 83 to $6 \%$ ) and that of the panicle smaller (changing from 12 to $52 \%$ ) than that of corresponding organs of the main shoot. The increased under $\mathrm{N}$ influence total phoitosynthetic activity was due, similarly as in the main shoot, to an increased $\mathrm{CO}_{2}$ fixation before heading mainly in laminae and in later stages also in sheaths as well as in the panicle.

Assimilate translocation from laminae was relatively rapid at all investigated stages. In 'Udycz żółty' (expt. I) seven hours (during which reassimilation also occurred) after exposure about 50 and overnight only about $20-25$ percent of ${ }^{14} \mathrm{C}$ was found in these organs. Five days later the amounits of labelled carbon in laminae were similar to those found at ripeness. The degree of translocation at higher $\mathrm{N}$ level was similar as in the control.

The main acceptors of assimilates formed 3-4 days prior to heading were the panicle as well as the culm. The amount of ${ }^{14} \mathrm{C}$ found in the panicle in the evening of the day of exposure was even higher than in the next morning and also higher than at ripeness (including kernels). The assimilates formed soon after heading were directed from leaves mainly to the culm and a great proportion of them, especially after the $65^{\text {th }}$ day gradually moved from this organ to the kernels. The distribution of the total amounits of ${ }^{14} \mathrm{C}$ as well as of its soluble fraction in the culm (Table 12) indicates that the second and third internodes were the main donors in this process. Phatosynthates formed in the later period were 
Table 12

Changes in radioactivity (total and ethanol - soluble fraction) in the main shoot at low nitrogen level - per cent of total shoot activity immediately after exposure

\begin{tabular}{|c|c|c|c|c|c|c|c|c|c|c|c|c|c|c|c|}
\hline \multirow{4}{*}{ Exposure } & \multirow{4}{*}{$\begin{array}{l}\text { Time } \\
\text { after } \\
\text { expo- } \\
\text { sure } \\
\text { days }\end{array}$} & \multirow{2}{*}{\multicolumn{2}{|c|}{ Leaves }} & \multicolumn{8}{|c|}{ Internodes $^{1}$ ) } & \multirow{2}{*}{\multicolumn{2}{|c|}{ Panicle }} & \multirow{2}{*}{\multicolumn{2}{|c|}{ Kernels }} \\
\hline & & & & \multicolumn{2}{|c|}{1 st } & \multicolumn{2}{|c|}{$2^{\text {nd }}+3^{\text {rd }}$} & \multicolumn{2}{|c|}{ rem. } & \multicolumn{2}{|c|}{ total } & & & & \\
\hline & & \multicolumn{14}{|c|}{ radioactivity } \\
\hline & & total & $\begin{array}{c}\text { solu- } \\
\text { ble }\end{array}$ & total & $\begin{array}{l}\text { solu- } \\
\text { ble }\end{array}$ & total & $\begin{array}{l}\text { solu- } \\
\text { ble }\end{array}$ & total & $\begin{array}{l}\text { solu- } \\
\text { ble }\end{array}$ & total & $\begin{array}{c}\text { solu- } \\
\text { ble }\end{array}$ & total & $\begin{array}{l}\text { solu- } \\
\text { ble }\end{array}$ & total & $\begin{array}{c}\text { solu- } \\
\text { ble }\end{array}$ \\
\hline
\end{tabular}

Experiment I

\begin{tabular}{|c|c|c|c|c|c|c|c|c|c|c|c|c|c|c|c|}
\hline \multirow{4}{*}{ 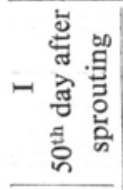 } & 1 & 33 & 21 & 2 & tr. & 13 & 7 & 7 & 4 & 22 & 11 & 16 & 9 & & \\
\hline & 5 & 21 & 7 & 2 & 1 & 15 & 5 & 5 & 1 & 22 & 7 & 20 & 4 & & \\
\hline & 15 & 17 & 3 & 2 & tr. & 15 & 2 & 5 & 1 & 22 & 4 & 7 & 1 & 11 & 1 \\
\hline & 41 & 11 & 1 & 2 & tr. & 14 & 1 & 2 & tr. & 18 & 1 & 7 & tr. & 10 & tr. \\
\hline \multirow{4}{*}{ 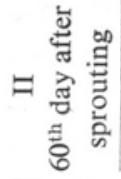 } & 1 & 25 & 17 & 12 & 6 & 17 & 10 & $\left.8^{2}\right)$ & 7 & 37 & 23 & 7 & 6 & 11 & 7 \\
\hline & 5 & 8 & 6 & 20 & 4 & 19 & 10 & 5 & 4 & 44 & 18 & 3 & 1 & 21 & 6 \\
\hline & 15 & 5 & 2 & 18 & 2 & 10 & 4 & 2 & 1 & 30 & 7 & 2 & 1 & 31 & 10 \\
\hline & 31 & 4 & 2 & 16 & tr. & 7 & 1 & 1 & tr. & 24 & 2 & 1 & tr. & 37 & 4 \\
\hline
\end{tabular}

Experiment II

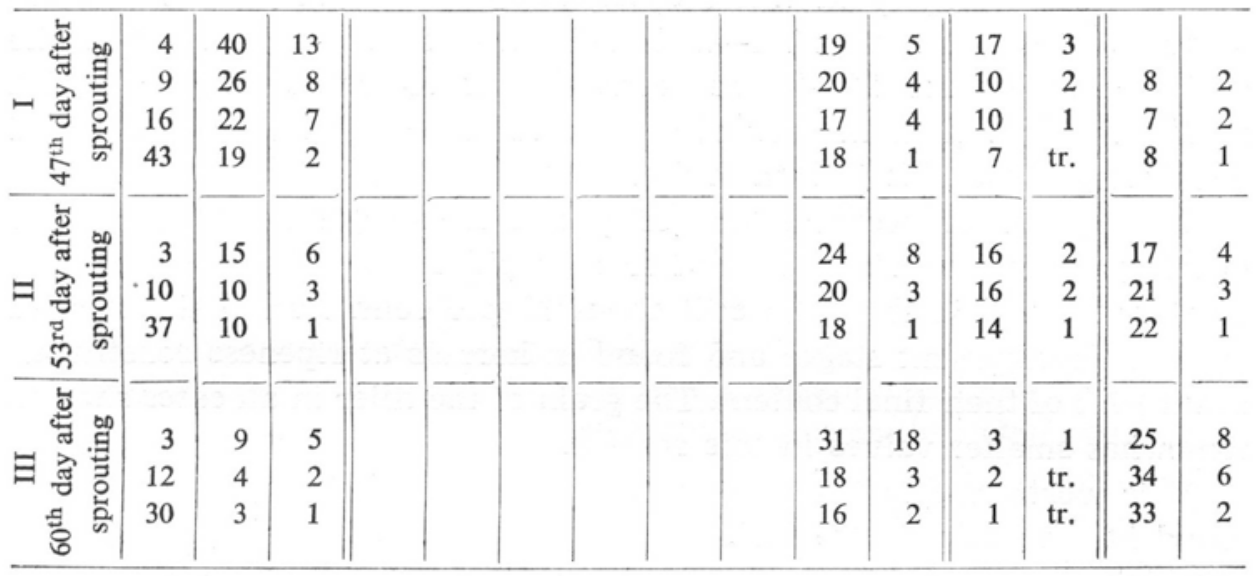

1) 1 st - uppermost, rem. - remaining.

$\left.{ }^{2}\right)$ About $4 \%$ in the 4 th internode.

rapidly accumulating in the kernels. Similar phenomena in translocation and redistribution were observed in the main shoot as well as in the tiller of the controls in expt. II.

The losses of ${ }^{14} \mathrm{C}$-assimilates from the aerial plant part were considerable nat only during the first day after their formation but also in the following period. In expt. I the amount of carbon assimilated some days before heading and found finally at ripeness in the main shoot of the control accounted for about 50 per cent of its initial value, not only in 'Udycz Zólty', but also in 'Avena B/H'. Photosynthates formed after 
heading (the last period excepted) were found at ripeness in amounts not exceeding $60-65$ per cent of their initial, in all investigated varieties*.

In expt. II the relative losses of assimilates formed in the main shoot before heading were somewhat less. It should be added that in the tiller the final accumulation of ${ }^{14} \mathrm{C}$, independently of the time of its fixation, was significantly lower than that in the main shoot and did not exceed 50 per cent of the initial amounts. Relatively great losses of assimilates in the tiller were also observed in expt. I at high nitrogen level. The tillers shaded during exposure did not show at ripeness any significant radioactivity. It is worth noting that in expt. II the radioactivity of new tillers that appeared 4 days after exposure of 47 -days-old plants (at high $\mathrm{N}$ level) to ${ }^{14} \mathrm{CO}_{2}$ accounted for about $2.10^{3} \mathrm{cpm}$, i.e. only $2 \%$ of the activity of sterile tillers and $0.1 \%$ of the total plant activity.

The final distribution of carbon in the main shoot as well as in the tiller depended on the period of its assimilation. In control plants photosynthates formed a week before heading (expt. II) and incorporated into the leaves constituted about 40 and those in the culm 35 per cent of their total amounts found at ripeness; however, about 15 per cent was incorporated also into the kernels. The carbon reassimilation process does not seem to play in this respect an important role. The relative amounits of ${ }^{14} \mathrm{C}$ assimilated $4-2$ days before heading and found in the grain accounted for $23-36$ per cent (plants of 'Avena B/H' supplied similar results). A great proportion of carbon assimilated in this period was incorporated also into the culm.

The degree of accumulation of photosynthates, formed soon after heading (strictly speaking soon after anthesis) reached in the kernels as much as 60 and in the culm still about 30 per cent. Assimilates formed in later development stages and found in kernels at ripeness constituted about $90 \%$ of their final content. The grain of the tiller in all cases showed somewhat smaller values in this respect.

It is worth noting that the final amounts of labelled photosynthates found in the grain of the main shoot, the uppermost lamina and sheath of which were shaded during exposure to ${ }^{14} \mathrm{CO}_{2}$ (expt. I), were lower than in the control. The difference in carbon fixed before heading was about 10 , in that fixed soon after heading 25 and that fixed on the $70^{\text {th }}$ day of growth about 32 per cent (the contribution of the flag leaf to total photosynthesis was at corresponding exposures 17, 18 and 26 per cent).

* Translocation and changes in the relative content of ${ }^{14} \mathrm{C}$-assimilates in Avena $\mathrm{B} / \mathrm{H}$ as well as Blenda were similar to those observed in Udycz Źółty. Therefore in Fig. 2 the distribution of ${ }^{14} \mathrm{C}$ only at ripeness is presented. The higher in Blenda than in Avena $\mathrm{B} / \mathrm{H}$ final amounts of ${ }^{14} \mathrm{C}$ assimilated till the $70^{\text {th }}$ day of growth (Table 8 ) find confirmation in the higher dry weight increments in this period. 
The final amounts of carbon in the main shoot of plants grown on high $\mathrm{N}$ level were in all cases larger than those in the controls. However, in both experiment differences in this respect were smaller than those in the total shoot photosynthetic activity.

Better $\mathrm{N}$ supply had no significant influence on the accumulation in kernels of carbon assimilated before heading; its higher amounts were incorporated mainly inito the culm and also but to a smaller degree into the panicle. Larger amounts of assimilates formed soon after heading were already found not only in the culm but also in the kernels. Photosynthates formed in the later period were accumulated in greater quantities only in the kernels.

In the fertile tiller (expt. II) at high $\mathrm{N}$ level the absolute losses of carbon were also higher than those in the control, however the relative difference between treatments in the final accumulation of photosynthates were greater than in the main shoot. In contrast to the latter the increased accumulation of carbon assimilated before heading was manifested by all parts of the tiller including kernels. It should be, however added that the relative amounts of carbon assimilated soon after heading and found in the kernels was somewhat lower and that in the vegetative parts higher than in the conitrol.

\section{DISCUSSION}

The investigated three oat varieties showed under similar conditions of growth, significant differences in the size of the upper and the lower leaf laminae, in changes with time in their total green area and in chlorophyll content per $\mathrm{dm}^{2}$. Under experimental conditions 'Avena $\mathrm{B} / \mathrm{H}$ ' and 'Blenda' differed markedly from each other in the rate of photosynthesis in their laminae. The total photosynthetic activity of both varieties at various development stages was not similar. One can hardly compare with them the plants var. 'Udycz Źółty', to which the greatest attention was paid, because they were exposed to ${ }^{14} \mathrm{CO}_{2}$ separately. The three varieties showed differences in the culm weight, in total dry matter increments before and after heading, in the number of kernels as well as in their final yield. It is difficult - at least on the bases of the data obtained - to distinguish among the listed factors one, which could be considered as mainly determining the productivity of the investigated planits.

Oat plants as compared to previously investigated spring wheat and barley showed the lowest rate of productive tillering; the better $\mathrm{N}$ supply at shooting had no effect on it (expt. II) and caused only an increase in growth of the existing fertile tiller. Although the three species showed significant differences in the length of the period between heading and ripening (or the end of weight increment) the relative increase in the 
total dry weight of the main shoot after heading in control plants was similar, amounting to about 40-45 per cent of their final weight.

Similarly as in wheat and barley the culm in oats played partly the role of a temporary store for assimilates, which, unless they were incorporated into this organ, at the stage of intensive grain filling moved to the kernels. In all these species a proportion of carbon assimilated before heading contributed to the final accumulation of organic compounds in the grain. In this respect oats plants resemble more barley than wheat plants, which showed the relatively lowest contribution. A greater resemblence to barley than to the latter species is manifested also in the contribution of individual green parts to the total shoot photosynthetic activity at various development stages. Thus, the role of the uppermost leaf including the corresponding internode was in oats significantly smaller and that of the lower ones higher than in wheat. The differences were due to a high extent to differences in the photosynthetic activity of the lamina. The contribution of the panicle in oats, especially in the first period after heading was greater than in wheat and resembled more that of the barley ear. The relatively very low role in photosynthesis of the culm of oats shoot is worth noting. The question arises, to what extent the conditions, under which exposure to ${ }^{14} \mathrm{CO}_{2}$ took place, influenced the contribution of particular green parts at various development stages. The great influence especially of light conditions on the total shoot photosynthetic activity was clearly demonstrated in the experiments with oats. This fact is particularly important, when differences in the rate of photosynthesis per area unit between leaves of various insertion order are under consideration.

The highest, under experimental conditions, photosynthesis rate $18 \mathrm{mg} \mathrm{CO} \mathrm{CO}_{2} \cdot \mathrm{dm}^{-2} \cdot \mathrm{h}^{-1}$, taking into account the initial $\mathrm{CO}_{2}$ concentration in the box, cannot be considered as the highest value obtainable at light saturation point ( $G$ a a stra 1963). It is true that differences in the photosynthesis rate between corresponding leaves of 'Avena $\mathrm{B} / \mathrm{H}$ ' and 'Blenda' as well as between the lower laminae 'of 'Udycz Źółty' in dependence on $\mathrm{N}$ supply under identical conditions indicate that neither light intensity (nor temperature) was the main limiting factor, at least in the case of control plants. However, the data obtained cannot be considered as fully reliable indications either of the photosynthetic capability of the upper or lower laminae, determined by their age or of their possible photosynthetic activity under field conditions. More detailed investigations under various light, temperature and $\mathrm{CO}_{2}$ conditions are necessarry in order to elucidate this problem. Horwever, taking account of the aforementioned facts and also the fact that 1) the contribution of particular green parts at corresponding development stages was similar in both years of experiments, 2) the character of differences between laminae in dependence of their insertion order or $\mathrm{N}$ influence 
was similar in exposures following each other at close dates but significantly differing as regards light and temperature conditions and finally 3 ) the highest observed photosynithesis rate did not deviate much from that observed under natural conditions ( $R$ a binowitch 1951, Verdu in 1953, M o n te ith 1962), the results obtained can be considered as reflecting to a high extent photosynthesis - in relative values outside the box during the period under investigation.

It was shown that differences in the rate of $\mathrm{CO}_{2}$ assimilation between oat varieties can exist; maybe, these differences in the reported experiments were partially due to the fact that one of the parents of 'Avena B/H' belongs to a different Avena species. However, varietal differences were observed also in spring wheat, to which such a structure does not apply.

The data concerning photosynthesis in laminae of various insertion order, in individual green sheaths as well as internodes show that neither total green area and leaf area index nor the green area above the uppermost node after heading or anthesis cannot serve as a fully satisfatory criterion of the plant productivity; the more so that differences between leaves of various insertion order in the rate of photosynthesis greatly depend, as shown, on the $\mathrm{N}$ status. It is worth noting that the influence of nitrogen applied at shooting on the ageing of laminae as well as on the photosynthesis rate in oats resembled more its influence observed in wheat than that in barley plants. It does not seem that the main cause of this fact is connected with differences in chlorophyll content. The question of the reaction of various plants to $\mathrm{N}$ as regards photosynthesis rate need more detailed investigations under more controlled conditions.

It has been shown that in var. 'Udycz Żółty' better $N$ supply at shooting brought about a higher by about $20 \%$ tatal weight increment of the main shoot in the period from heading to ripeness; this was reflected mainly in the weight of the culm and grain yield (the differences in the total final ${ }^{14} \mathrm{C}$ content between treatments were also of a similar order). In 'Avena $\mathrm{B} / \mathrm{H}$ ' and 'Blenda' no significan't influence of $\mathrm{N}$ in this respect was observed. The question whether the differences between varieties are due to differences in the time of the differentiation* of floral primordia, in their survival or (and) in the reaction of the tillers or else cannot be here answered. It should be noted that in 'Udycz Źółty', in contrast to the other varieties, the higher due to $\mathrm{N}$ yield of kernels in the main shoot was accompanied by their greater number. The number of kernels per shoot seems to be of importance not only as regards varietal differences (Bunting et all. 1964).

* This problem was discussed in detail in the previous publication (B i recka, Skupińska. Bersntein, 1967). 
The differences caused by nitrogen in the contribution of photosynthates formed at various stages to the grain yield of the main shoot in 'Udycz Żółty' were, similarly as in spring wheat varieties, due mainly to carbon assimilated after anthesis.

As it was shown the relative losses of assimilates in the tiller were always higher than those in the main shoot. It is possible that this is due not only to a higher degree of assimilate utilisation in respiration in the upper parts, but also to a relatively greater translocation to the root.

The rapid translocation of great proportions of assimilates to the panicle even at the early stages indicate that this organ including kernels, especially in the main shoot could be responsible in a high degree for the losses observed. The changes with time in the content of labelled carbon in these parts suggest that the losses in them at higher $\mathrm{N}$ level were relatively greater.

There is one problem more that should be mentioned, i.e. the question of isotope dilution and the possible errors which it could involve in the here as well as previously reported experiments. This concerns mainly differences in the radioactivity of plants in dependence on $\mathrm{N}$ supply. The data obtained at each exposure to ${ }^{14} \mathrm{CO}_{2}$, which lasted only 20 30 min either in the morning or in the afternoon, were considered as representing the mean daily (or within a certain period of time) differences between treatments in their photosynthetic activity. If the differences indicated by the ${ }^{14} \mathrm{C}$ content had deviated much from the true values, the isotope dilution (by nonlabelled assimilates) would be in both treatments different causing erroneous conclusions, especially as regards differences in the final accumulation and distribution of photosynthates.

The photosynthetic activity of the investigated plants was not checked by any other method than that reported here. However, in all experiments the differences observed in plant radioactivity and its distribution at ripeness and even at earlier stages find confirmations in various facts, partly in changes and differences in the total dry weights and also in the weights of culm as well as of grain.

Thus, it may be assumed that the differences between treatments indicated by ${ }^{14} \mathrm{C}$ at various development stages did not deviate much from the true mean values.

\section{SUMMARY}

Three investigated oat varieties, 'U.dycz Żółty', 'Blenda' and 'Avena B/H' showed under similar conditions of growth significant differences in the size of laminae, in changes with time in their total green area and in the chlorophyll content per $\mathrm{dm}^{2}$. Differences in the rate of photosynthesis per green area unit were also found. Var. 'Udycz' showed the highest final weight of the culm as well as the highest number and yield of 'kernels. 
The contribution of individual green parts to the total photosynthetic activity of the main shoot at various development stages in all varieties resembled more that found in previously investigated barley than wheat plants. The contribution of the uppermost leaf including the corresponding internode even at the later development stage did not exceed 30 and that of the panicle ranged for a long time after heading from 22 to 30 per cent of the totai shoot activity.

In 'Udycz Żółty' the higher nitrogen dose applied at shooting delayed senescence of green organs, especially of the leaves; this was revealed in changes in their green area after heading, in chlorophyll content as well an in the photosynthesis rate per area unit. Leaves of various insertion order differed from each other in their reaction to nitrogen. The higher total shoot activity was mainly due to a greater $\mathrm{CO}_{2}$ fixation in the laminae. At later stages after heading some increase in this respect was observed also in sheaths and in the panicle. The reaction of the fertile tiller to nitrogen was greater than that of the main shoot. Although at higher $\mathrm{N}$ level the total loss of assimilates formed at various stages was greater, their final amounts found in the main shoot and especially in the tiller at ripeness were always higher than in plants grown on low $\mathrm{N}$ level.

The higher due to $\mathrm{N}$ weight increase of the main shoot in 'Udycz Źólty' was revealed mainly in a higher yield (and number) of the kernels and weight of the culm. In 'Blenda' and 'Avena $\mathrm{B} / \mathrm{H}$ ' no significant influence of nitrogen in this respect was observed. On the other hand the reaction of their tiller was greater than in 'Udycz Żólty'.

The amount of carbon assimilated $7-2$ days before heading and finally found in grain accounted in the investigated varieties for about $16-36$ per cent. respectively, of its total at ripeness. The contribution of photosynthates formed after heading was much higher, reaching at later stages about 90 per cent. The greater final accumulation of organic substances under $\mathrm{N}$ influence in the kernels of the main shoot in 'Udycz Żółty' was due almost entirely to assimilates formed after heading.

The authors are much indebted to professor T. Ruebenbauer for supplying the seeds of the investigated plants as well as to Miss E. Szczypa M. sci. for her help in plant analysis.

Plant Physiology Department

(Entered: April 15, 1967)

Agricultural University, Warsaw.

Plant Physiology Division

Institute of Soil Science

and Plant Cultivation.

REFERENCES

Birecka H., Dakic-Włodkowska L., 1966, Acta Soc. Bot. Pol., 35(4):638. Birecka H., Skupińska J., Bernstein I., 1967, ibidem, 36(2).

Bunting A. H., Drennan D. S. H., de Silva W. H., Krishnamurthy K., 1964, Abstr. 10 Inter. Bot. Congress, 11.

G a a str a P., 1963, Climatic Control of Photosynthesis and Respiration, Acad. Press. New York, 113.

M on te ith J. L., 1962, Neth. J. Agric. Sci., (10(5):334.

R abinovitch E., 1951, Photosynthesis and Related Processes, II part 1, Inter.

Pub., Inc., New York.

Verduin J., 1953, Amer. J. Bot., 40(9):675. 


\section{Aktywność fotosyntezy $i$ jej produktywność w roślinach owsa przed $i$ po wykloszeniu}

\section{Streszczenie}

Przebadano w warunkach wazonowych trzy odmiany owsa: 'Udycz Źółty' 'Blenda' i 'Avena B/H' (stanowiącą krzyżówkę pomiędzy Avena bisantina i Avena sativa var. 'Heines'). W różnych fazach wzrostu, poczynając od 44-45 dnia, część roślin umieszczano na $20-30$ min. w atmosferze zawierającej dwutlenek węgla znakowany ${ }^{14} \mathrm{C}$. Ich radioaktywność oznaczano bezpośrednio po ekspozycji oraz w różnych odstępach czasu aż do dojrzenia. Badane rośliny w analogicznych warun"kach wzrostu wykazywały istotne różnice w wielkości blaszek liściowych, w zmianach ich ogólnej powierzchni zielonej oraz w zawartości chlorofilu w przeliczeniu na $\mathrm{dm}^{2}$. Stwiєrdzono również różnice $\mathrm{w}$ intensywności fotosyntezy $\mathrm{w}$ przeliczeniu na jednostkę powierzchni. 'Udy.cz Żółty' wykazywał największy końcowy ciężar źdźbła, jak i najwięlkszą liczbę oraz ciężar ziarniaków.

U wszystkich odmian udział poszczególnych organów zielonych w ogólnej aktywności fotosyntetycznej pędu głównego w różnych fazach rozwoju był bardziej podobny do udziału obserwowanego uprzednio $\mathrm{w}$ roślinach jęczmienia niż w roślinach pszenicy. Udział liścia najwyższego piętra (flagowego) ląoznie z odpowiadającym mu międzywęźlem nie przewyższał nawet w późniejszych fazach wegetacji $30 \%$, a udział wiechy w ciągu stosunkowo długiego okresu po wykłoszeniu wahał się w granicach $22-30 \%$ ogólnej akiywności pędu.

W odmianie 'Udycz Żółty' większa dawka azotu zastosowana w okresie strzelania w źdźbło opóźniła starzenie zielonych organów, w szczególności liści; przejawiało się to $\mathrm{w}$ zmianach $\mathrm{w}$ ich powierzchni zielonej po wykłoszeniu, zawartości chlorofilu oraz $\mathrm{w}$ aktywności fotosyntetycznej $\mathrm{w}$ przeliczeniu na jednostkę powierzchni. Blaszki liści różnego piętra wykazywały różnice w swej reakcji na azot. Wyższa ogólna aktywność fotosyntetyczna pędu głównego była przede wszystkim wynikiem wiẹkszej aktywności blaszek liściowych, a w późnych fazach po wykłoszeniu również $i$ pochew oraz wiechy. Chociaż w warunkkach lepszego zaopatrzenia w azot ogólne istraty asymilatów powstałych w różnych fazach były wyższe, ich ilości stwierdzone w końcu wegetacji w pędzie głównym, a szczególnie w pędzie bocznym były zawsze większe niż w roślinach wyrosłych na niższym poziomie N. Większy dzięki temu składnikowi przyrost masy pędu głównego roślin odmiany 'Udycz Żółty' przejawił się głównie w ciężarze (i liczbie) ziarniaków oraz w ciężarze źdźbła.

W odmianie 'Bl€nda' i 'Avena $\mathrm{B} / \mathrm{H}$ ' nie obserwowano pod tym względem istotnego wpływu azotu.

W fazie pełnej dojrzałości w ziarnie roślin badanych odmian stwierdzono około $16-36 \%$ pozostałej $\mathrm{w}$ nich ilości węgla zasymilowanego $7-2$ dni przed kłoszeniem; względna akumulacja asymilatów utworzonych po wykłoszeniu była wyższa dochodząc do $90 \%$ w przypadku związków organicznych powstałych w późnych fazach. W większym pod wpływem azotu nagromadzeniu tych związków w ziarniakach pędu głównego roślin odmiany 'Udycz Żółty' podstawową rolę odegrał węgiel zasymilowany po kłoszeniu. 